\title{
A COMPARISON OF THE IMPACTS BETWEEN TURKEY AND FIVE SELECTED DEVELOPING ECONOMIES DURING THE GLOBAL FINANCIAL CRISIS
}

DOI: 10.17261/Pressacademia.2020.1314

JBEF- V.9-ISS.4-2020(5)-p.336-346

\section{Sercan Arman Kandemir}

Istanbul Medeniyet University, Economics Department, Kadıkoy, Istanbul, Turkey. sercanarman@gmail.com, ORCID: 0000-0003-4145-2014

Date Received: September 21, 2020

Date Accepted: December 2, 2020

\section{To cite this document}

Kandemir, S.A., (2020). A comparison of the impacts between Turkey and five selected developing economies during the global financial crisis. Journal of Business, Economics and Finance (JBEF), V.9(4), p.336-346.

Permanent link to this document: http://doi.org/10.17261/Pressacademia.2020.1314

Copyright: Published by PressAcademia and limited licensed re-use rights only.

\begin{abstract}
Purpose- We would like to examine the impacts of the global economic crisis on the Turkish economy and compare it with some other developing economies like Brazil, Russian Federation, India, China, and South Africa, namely the BRICS countries. We chose these countries because they are well-known developing countries in the world.

Methodology- We compared the economic variables of unemployment rates, current deficit, GDP growth, and foreign direct investments for each country. Therefore, we obtained statistics from the World Bank and analyzed them.

Findings- The banking and financial sector showed a similar trend in all countries. Developing countries did not take a direct hit to the banking sector because of robust regulations in the banking sector, relatively low toxic assets, and fiscal \& monetary measures taken in developing countries. Consequently, country-specific factors played an essential role in some countries. Especially for South Africa, the FIFA World Cup held in 2010 was influential in offsetting the crisis's adverse effects. Also, for the Russian Federation, Georgia's occupation in 2008 led to the protest against Russian goods, and therefore demand for Russian goods decreased

Conclusion- As a result, it is concluded that Turkey and the Russian Federation were directly hit by the crisis with substantial reductions in economic growth and unemployment rates. In China, India, Brazil, and South Africa, GDP growth and unemployment rates did not change greatly. Except for Turkey and the Russian Federation, other countries were not primarily affected by the global financial crisis. For the current account balance, there is a whole different scenario. Commodity and oil exporter countries like Russia were severely affected by decreasing oil prices in terms of the current account. Meanwhile, oil and commodity importer countries like Turkey were less damaged and had their lowest current account deficit in this era
\end{abstract}

Keywords: Crisis, economic growth, unemployment, BRICS, economic indicators JEL Codes: B26, G01, E00

\section{INTRODUCTION}

The global financial crisis was one of the best-known economic events in the world. It had severe effects on the world economy as a whole. These impacts are effective even today. The EU Banks' excessive risk-taking behavior and the US housing bubble led to an economic disaster. Most economists regard it as the worst economic crisis after the Great Depression. The European debt crisis followed the great recession. This study will examine the effects of the global financial crisis on some selected economies, namely Turkey, the Russian Federation, China, South Africa, and Brazil.

Before 2009, the subprime mortgage market disruptions led to a crisis in the real estate sector and housing. Stock prices of subprime mortgage lender companies began to fall rapidly. The most obvious examples are the Lehman Brothers and City Group. Additionally, the global financial system has been affected by this situation as well. ECB injected more than 200 billion dollars to be able to control the financial crisis. In September 2008, US President George Bush decided to inject more than 700 billion dollars into the US Economy (Gotham, 2008). 
Banks used to lend mortgage funds only to creditworthy customers before 2000. New technological and statistical achievements led to giving credit to riskier consumers. Banks have taken advantage of this situation. They made enormous profits through subprime mortgage loans. Subprime mortgage means the type of loan granted to individuals with poor credit histories or a lack of covering loan payments. Computer technology has also decreased the transaction cost, making mortgage funds more reachable for the consumer.

Subprime mortgage loans have taken off after liquidity aids by countries such as India and China after the recession happened in 2001. Politicians and economists advocated developing subprime mortgages because it led to justice for mortgage credits, and U.S homeownership rates increased. An increase in subprime mortgages resulted in a demand increase in housing. Then, a rise in demands affected the prices of houses significantly. As long as house prices increase in the USA, profitability for mortgage investors and lenders was high. Thus, riskier borrowers had the opportunity to take a mortgage more and more because that mortgage relative to the house's value had increased.

After a peak in 2006, house prices began to decline sharply. When it peaked, many borrowers realized that their home value was below the value of the mortgage. Therefore, the motivation for borrowers to leave their homes greatly increased. This situation led to more than 1 million mortgages in foreclosure. This bubble burst in 2008 and caused a significant crisis not just in the USA but globally. Especially in the USA, banks held a massive amount of mortgage-backed securities and credit default swap agreements in their balance sheets. When they experienced the burst in 2008, most of the banks were affected negatively, and some of them became insolvent and went into bankruptcy like the Lehman Brothers.

Besides, as the banks had weak financial conditions, they began to give much fewer loans to the economy. Thus, the US economy and then the global economy has started to experience a recession. Between 2008 and 2009, GDP growth reduced from $4.31 \%$ to $-1.78 \%$, which means over one year, there was a $5 \%$ decline in the world economic growth. Foreign Direct Investment decreased substantially net inflows of FDI to GDP ratio. It had been increasing since 2003, and it was almost $5 \%$ in 2007 , but it could not return to this level after 2008. The balance sheets of many financial intermediaries, notably the banks, deteriorated sharply due to the USA's house prices, and the value of mortgage-backed securities and Collateralized Debt Obligation collapsed. Because of the weaker balance sheets, banks began to sell assets. They limited credit availability to the firms and individual consumers (Mishkin, 2007).

In this study, we aim to examine the effects of the global financial crisis on emerging economies. Therefore, we try to analyze five developing countries, including Turkey, Russia, China, India, and South Africa, also known as the BRICS. Our conceptual analysis investigates the changes in GDP growth, foreign direct investment, unemployment rate, inflation rate, tax revenues, and nonperforming loans in these countries. As a result, we aim to compare these economic indicators across countries and analyze which country was affected more than others. In our comparisons, we used the World Bank Data.

It can be considered that Turkey and the Russian Federation have suffered the greatest loses from the and their economic activities have been greatly reduced. From current account perspective, commodity and oil exporter countries like Russia have been severely affected by falling oil prices. At the same time, oil and commodity importer countries like Turkey have suffered less damage and experienced the lowest current account deficit in this era. Due to large stimulus plan, China was a less affected country by the global financial crisis. Therefore, GDP growth has not decrease much in China.

In the next chapter, we will review the impacts of the 2008 crisis on the Turkish economy. In the third chapter, we will focus on the Russian economy. In the fourth chapter, we will look into the effects of the Chinese economy's mortgage crisis. In the fifth chapter, we will examine the effects of the subprime mortgage crisis on the South African economy. The sixth and seventh chapters will be about Brazilian and Indian economies. Lastly, the results will be discussed in the final chapter.

\section{IMPACTS ON TURKISH ECONOMY}

The crisis in 2008 has relatively the same as the other crises but somewhat different from them. Precautions that aim to reduce the budget and current account deficit existed in the previous crisis. However, there was only a decrease in interest rates and inflation in the recent crisis, and economic stimulus packages were put into effect to raise the budget deficit (Uygur, 2010). It can be seen that GDP growth reduced from $7 \%$ in 2007 to $-4.7 \%$ in 2009 in this case, which shows that there is some amount of reduction in crisis in both 1994 and 2001. Notably, the consumption part decreased by 1\% between the years 2007 and 2009. However, the main reason for this reduction is that foreign direct investment decreased between the same period.

Foreign direct investments were increasing between 2003 and 2007, and this situation suddenly turned negative worldwide in 2008. Turkey has also experienced this abundance of foreign capital. Foreign direct investments shrank from 22.04 billion dollars 
in 2007 to 8.6 billion dollars in 2009, which is almost a $60 \%$ decrease. Portfolio investments have shown a sharp decrease from 5.138 billion US dollars to 716 billion US dollars. These two factors together are one of the reasons that caused GDP growth to decrease. An unsustainable budget deficit with very high-interest rates and very high inflation led to a sudden financial reversal resulting in the collapse of the Turkish Lira. Turkish Lira depreciated by $30 \%$ against the US dollars between August 2008 and November 2008 (Cömert \& Çolak, 2014).

Since 1991, Turkey's average rate of unemployment has been $10.0 \%$ per annum. Turkey experienced a record unemployment rate in 2009 by $12.55 \%$. The unemployment rate in the young population (aged 15-24) is $24 \%$, and both males and females have the same figures. This situation is also true for the young population. Trade is an important aspect. The Turkish economy was affected mainly in this sector, mostly when two-thirds of Turkey's external trade was done with the EU countries. The EU's demand declined almost by half, and fortunately, this loss was almost compensated by eastern countries, but merchandise trade still decreased by $5 \%$ (Rodrik, 2009).

For the current account, there is a different case. Turkey is an oil and natural gas importer country. Since the oil prices declined and the appreciation of the Turkish Lira was observed, it can be said that the current account deficit contracted between 2006 and 2009. The peak for the current account to GDP ratio was nearly $2 \%$ in this period. Besides, the current account deficit was always at high levels in Turkey. While we could not see many contractions between 2008 and 2009 in exports, there was a reduction in imports. Also, there was a 4\% reduction in imports to GDP ratio between 2008 and 2009. Moreover, this is suggested to be an actual reason for the contradiction of the current account deficit through a depreciation of the Turkish Lira.

The inflation rate did not change after 2003 in Turkey. This rate based on consumer prices increased by $2 \%$ between 2007 and 2008 in the world and Turkey. However, a decline is observed in inflation by 5\% both in the world and in Turkey. Additionally, inflation rates increased from $8.7 \%$ to $10.4 \%$ between 2007 and 2008 . Thus, it can be claimed that there was not much difference after the expansionary policies in Turkey. There is also an essential aspect of the loan ratios here. Non-performing loans can be defined as the loans either defaulted or close to being defaulted. Share of non-performing loans in the total bank loans can give us an idea about a country's banking system and economy.

The share of the banks' capital in total assets was higher in Turkey than in the world and the United States. In risky periods, banks prefer to hold more capital to avoid the risk of being insolvent. Turkish banks preferred $3 \%$ more to hold capital than the others. Also, the share of banks' capital to total assets increased by $1 \%$. Basel Requirements indicates that $8 \%$ of the capital must be held as a reserve requirement, but it is $4 \%$ higher than the Basel Requirements in Turkey. Furthermore, no bank went bankrupt in Turkey. Because of the strong regulations and rules in the banking sector applied by the Savings Deposit Insurance Fund (SDIF), the banking sector did not take as much damage as in the crisis in 2001 . There were 18 banks to be transferred to the SDIF, and a state bank had gone bankrupt in 2001, but there was no bank transferred to SDIF in 2008 (Babacan, 2009).

It is also important to note that Turkish Banks were not holding Mortgage-Backed Securities and Collateralized Debt Obligations as much as the US banks. This preventive attitude helped most of the banks survive in Turkey alongside strong regulations. It can be seen that that ratio is not as high as it is in the banking crisis of 2001. The ratio of bank non-performing loans to total gross loans was 3.5 in 2008. Especially in 2009, even though non-performing loans share in total bank loan ratios increased slightly but quickly recovered until 2010 and remained under the global levels up until now. In Turkey, we may remark that the ratio of bad loans in total loans stood below the global levels after the global crisis. In this context, non-performing loans had increased by almost 20\% during the banking crisis in 2001.

There is also an essential fact about tax revenues. Government revenues increased between 2008 and 2010 in Turkey, precisely by $2 \%$ relative to GDP; however, the tax revenues decreased worldwide in the same period, and they could only return normal levels in 2012. Due to the lack of data, we cannot say much about tax revenues between 1998 and 2007. It is essential to express that government expenditures increased in Turkey more than the world average in this period. While the government expenditures increased by $6 \%$, government expenditures increased by $2 \%$ only for the world average. We believe that there are two reasons behind that. The first one is tax incentives due to incoming local elections, and the second one is the peace of the asset (reporting assets previously unrecorded and paying taxes based on that assets) by the Ministry of Finance.

Table 1 reflects that Turkey's GDP growth decreased until 2009, and it reached its lowest level in 2009. GDP growth was much higher in 2010 and 2011. In 2008 and 2009, net FDI inflows were at the lowest levels, as can be seen in Table 1. Unemployment rates were around $9 \%$ and stable between 2005 and 2012. We can also say that the same for the inflation rate. According to Table 1 , the current account deficit fell during the crisis, but later, it increased. 
Table 1: Economic Indicators for Turkey

\begin{tabular}{|c|c|c|c|c|c|}
\hline Year & $\begin{array}{l}\text { GDP } \\
\text { Growth }\end{array}$ & Net FDI Inflow & $\begin{array}{l}\text { Unemployment } \\
\text { Rate }\end{array}$ & Inflation Rate & $\begin{array}{l}\text { Current } \\
\text { Account to GDP }\end{array}$ \\
\hline 2005 & $\% 9.01$ & $10.03 \mathrm{Bn}$ USD & $\% 10.63$ & $\% 8.17$ & $\%-4,18$ \\
\hline 2006 & $\% 7.11$ & $20.18 \mathrm{Bn}$ USD & $\% 8.78$ & $\% 9.59$ & $\%-5.64$ \\
\hline 2007 & $\% 5.03$ & $22.04 \mathrm{Bn}$ USD & $\% 8.68$ & $\% 8.75$ & $\%-5.46$ \\
\hline 2008 & $\% 0.845$ & 19.85 Bn USD & $\% 9.71$ & $\% 10.44$ & $\%-5.15$ \\
\hline 2009 & $\%-4.74$ & 8.58 Bn USD & $\% 12.55$ & $\% 6.25$ & $\%-1,76$ \\
\hline 2010 & $\% 8.48$ & 9.09 Bn USD & $\% 10.66$ & $\% 8.56$ & $\%-5,78$ \\
\hline 2011 & \%11.13 & 16.18 Bn USD & $\% 8.79$ & $\% 6.47$ & $\%-8.93$ \\
\hline 2012 & $\% 4.79$ & 13.74 Bn USD & $\% 8.14$ & $\% 8.89$ & $\%-5,48$ \\
\hline
\end{tabular}

Source: World Bank Data

\section{IMPACTS ON RUSSIAN ECONOMY}

When the economic crisis hit Russia, it affected the country on three main channels: a drop in export prices, a decline in some export volumes, and a withdrawal of capital (Sutela, 2010). Like Turkey, Russia has also experienced rapid growth between 2003 and 2007. However, the main difference was that Russian economic growth depended on rising oil prices, and, similar to Turkey, economic growth depended on capital inflows from abroad. Unlike Turkey, Russia experienced a commodity price shock, which means oil prices have fallen (Conrad et. Al, 2009).

We must point it out that after the collapse of the Soviet Union, Russia's growth rate was the lowest. When the Soviet Union collapsed, a reduction in annual growth rates was about 13\% between 1991 and 1994, but during the global financial crisis, the Russian economy experienced a $-7,821 \%$ growth rate in 2007. This can be seen as a decline in GDP growth from 8.535 in 2007 to -7.821 . It is a reduction of nearly $15 \%$.

As we stated before, declining oil prices had a considerable role in this reduction for Russia and decreased FDI levels. Another aspect was military operations in Georgia, which negatively affected the Russian economy due to protests against Russian goods. Russia was not so different from other countries in the world in the case of FDI. Capital inflows increased continuously between 2001 and 2007. However, in a year, from 2007 to 2008, foreign direct investment decreased almost by half. This situation was one of the main factors behind the decrease in Russian growth rates.

Portfolio investments, which are the indirect investment made via bonds and equities, decreased in that period. Net portfolio inflows decreased from 18 billion US dollars to -15 billion dollars. Russia had the sharpest reduction in this category after India, with 33 billion dollars lost. Russian Federation was successful in reducing the unemployment rate. They managed to decrease the unemployment rate from $13.3 \%$ in 1998 to $6 \%$ in 2007 . According to our observation, this situation happened continuously, and there were a few points that unemployment rose by a small percentage or leveled. Nevertheless, unemployment levels suddenly rose to $8.3 \%$. However, the Russian Federation managed to sustain this low unemployment rate performance after the crisis.

We also noticed that there was a $1 \%$ difference between male and female unemployment levels in 2009 . In regular times, it was mostly less than $1 \%$. The woman's unemployment rate was only $7.7 \%$, but it was $8.9 \%$ for the man. We can clearly say that unemployment affected males slightly more than the females during the crisis in Russia. Before the global crisis between 1999 and 2006, a massive current account was observed in the Russian Federation. The ratio of the current account to GDP was $10 \%$ in this period. We also see that this current account surplus decreased sharply during the global economic crisis with the effect of decreasing oil prices, and Russia was one of the biggest oil and natural gas exporters in the world.

In Russia, exports decreased by almost 20\% between 2006 and 2009. We think that it is due to the decreasing oil prices in general. This situation also partly led to more fossil fuel use. Imports also decreased by $7 \%$ in Russia.

Between 2002 and 2008, the exchange rate of the ruble against dollar appreciated by $36 \%$. Therefore, it encouraged foreign borrowing and exports. However, as the crisis progressed, the devaluations became more frequent. Gradual devaluations allowed consumers to protect their savings and help the banking system stabilize. We should also note that gradual devolutions made foreign exchange speculation very profitable. To solve this problem, the Bank of Russia increased interest rates to stabilize devaluation expectations (Barannik, 2010). 
International investors cashed out their investment on Russian holdings (half of the Russian stock market at that time) to create cash and cover their obligations, so we observe a sharp decrease in Russian money markets' investment. The dollar-denominated RTS and ruble-denominated MICEX (Russian stock markets) fell by $20 \%$ on September 16,2008 . In order to make up for the loss, the Russian government formulated a rescue plan of 130-billion-dollar. (Barannik, 2010).

After the Soviet Union collapsed, Russia experienced hyperinflation, but the inflation rate was stabilized around $10 \%$ after 2000 . The inflation rate increased during these years. In 2007, the inflation rate was $8.9 \%$, but in 2008 it rose to $14.1 \%$. We see a $5 \%$ increase in inflation during that period. However, in 2015 , we see a sharper increase by a $15 \%$ inflation rate in Russia with stimulus packages. In terms of the bad credits in Russia, it can be seen that $10 \%$ of the total loans defaulted, or they were close to being the default. This case resulted in a huge increase in non-performing loans to total gross loans ratio after 2003 . This ratio was almost stable, with $3 \%$. This ratio was higher than the world level, almost $6 \%$ higher.

Like Turkish Banks, Russian Banks preferred to hold more of their capital in total assets. Unlike Turkey, we see a sharp reduction (from 13.3\% to $10 \%$ between 2007 and 2008) and a sharp increase (from 10\% to 13\%). We also see a sharp decline in tax revenues in Russia by almost $6 \%$. Furthermore, in the world, tax revenues decreased by only $2 \%$ on average. This indicates that the Russian government could experience losses on collecting taxes more than other governments. Besides, Russia effectively used fiscal policy in the global financial crisis. Government expenditures increased by almost 20\% between 2008 and 2009 . The Russian Federation's Government successfully liquidated the Russian Economy via direct support to stock markets and banking sector and fiscal support to maintain the exchange rate system (Barannik, 2010).

As Table 2 indicates, Russian's GDP growth was stable until 2009, and it reached its lowest level in 2009. After 2009, the GDP growth was around 4\%. In 2009, net FDI inflows were at the lowest levels in Russia except for 2005. The unemployment rate reached a peak in 2009, but it decreased after 2009. In Russia, the inflation rate was quite high in 2008 but decreased after that. According to Table 2, Russia had a current account surplus before the crisis. After the crisis, the amount of current account surplus decreased.

Table 2: Economic Indicators for Russia

\begin{tabular}{llllll}
\hline Year & $\begin{array}{l}\text { GDP } \\
\text { Growth }\end{array}$ & Net FDI Inflow & $\begin{array}{l}\text { Unemployment } \\
\text { Rate }\end{array}$ & Inflation Rate & $\begin{array}{l}\text { Current } \\
\text { Account to GDP }\end{array}$ \\
\hline 2005 & $\% 6.4$ & 15.50 Bn USD & $\% 7.12$ & $\% 12.68$ & $\% 11.04$ \\
\hline 2006 & $\% 8.2$ & 37.59 Bn USD & $\% 7.05$ & $\% 9.69$ & $\% 9.32$ \\
\hline 2007 & $\% 8.5$ & 55.87 Bn USD & $\% 6.00$ & $\% 9.00$ & $\% 5.55$ \\
\hline 2008 & $\% 5.2$ & 74.78 Bn USD & $\% 6.20$ & $\% 14.11$ & $\% 6.25$ \\
\hline 2009 & $\%-7.8$ & 36.58 Bn USD & $\% 8.30$ & $\% 11.64$ & $\% 4.12$ \\
\hline 2010 & $\% 4.5$ & 43.16 Bn USD & $\% 7.36$ & $\% 6.84$ & $\% 4.42$ \\
\hline 2011 & $\% 4.3$ & 55.08 Bn USD & $\% 6.53$ & $\% 8.44$ & $\% 3.28$ \\
\hline 2012 & $\% 4.02$ & 50.58 Bn USD & $\% 5.43$ & $\% 5.07$ & \\
\hline
\end{tabular}

Source: World Bank Data

\section{IMPACTS ON CHINESE ECONOMY}

The Chinese economy was affected in many ways by the global financial crisis. Perhaps the most crucial channel was the trade for the Chinese economy. Exports and imports decreased by almost 30\% in China between 2007 and 2009 (Whalley, 2011). It can be said that steel exports have one of the primary roles in reducing trade decrease. The reduction in steel exports was the most affected part of the exports. This reduction was due to the overall production of steel in China. We can explain fifty-four percent of the decrease in steel exports with a decrease in steel production. Moreover, a decrease in demand in the steel-related industries was substantially significant (Yongding, 2010).

Growth levels in China steadily increased between 2003 and 2007, and it had a peak of 14\% in 2007. Besides, the average GDP growth in China between 2001 and 2007 was 10\%. Growth rates decreased between 2007 and 2009, but unlike the other countries we analyzed before (Turkey and Russia), it did not have negative values, nor were there significant changes. Chinese economy did not contract thanks to the Chinese economy's immediate intervention, and the growth rate decreased by $5 \%$ in two years. The Chinese government launched a stimulus package amounted to 580 billion dollars, equal to $15 \%$ of Chinese GDP in November 2008 for 2008 and 2009. Half of this stimulus package went into infrastructure services, and the Chinese government used a quarter of the stimulus package for the reconstruction due to the Sichuan earthquake (Yongding, 2010). 
This stimulus package compensated for the adverse effects of the global crisis on the Chinese Economy. It mainly included housing, rural infrastructure, transportation, health and education, environment, industry, disaster rebuilding, incomes, taxes, and finance. We think that the answer to how China continued to grow by $8 \%$ is behind this stimulus package. This stimulus package explained why the unemployment rates stood at low levels during the global crisis.

China experienced a sharp increase in FDI until 2008, but a decline was seen between 2008 and 2009. After global economic crisis, net FDI inflows increased almost $30 \%$. We cannot see such a sharp increase in other countries. Portfolio investments increased after 2001, and we observed a peak in 2006, which has a total amount of 42 billion dollars. However, after 2006, this case changed. Portfolio investments from the rest of the world gradually decreased in China. The total amount of portfolio decreased to nearly 8 billion US dollars.

In China, unemployment decreased as of 1999 and stood below 5\% after 1991. Unemployment increased from 3.8 to 4.4 between 2007 and 2009. Compared with the countries analyzed previously, this change is insignificant. In addition, the decline in the male unemployment rate was significantly greater than the decline in the female unemployment rate. The share of the current account in GDP continuously increased between 2002 and 2007, and it peaked in 2007, which indicates the share of the current account surplus in GDP was equal to 10\%. However, after 2008 it began to decrease, and China could not reach pre-crisis levels in current account surplus. The country barely reached $5 \%$ level after the global crisis occurred. The average share of the current account in GDP was about seven percent between 2004 and 2008. However, nowadays, especially after 2010, China could not keep up with the pre-crisis levels in this category.

In China, a decrease in exports and imports began before the global financial crisis, and during the financial crisis, the magnitude got even higher. So, it can be seen that they both decreased by almost 30\% between 2007 and 2009 . The main reduction occurs in EU-China and EU-US Trade because EU and US shares in Chinese trade are thirty percent together. During the global crisis, they both decreased by approximately $6 \%$. There is no doubt that China was affected by the global crisis in the sense of export and import during the global crisis (Bai, 2012). We also observe a sharp increase in RMB. Between 1992 and 2008, the US dollar depreciated by $21 \%$, but it suffered by $6 \%$ in the first eight months of 2008 . This situation also caused the export values to decrease in China (Sun, 2009).

Non-performing loans to total loans ratio was above $10 \%$ between 1999 and 2004. These ratio was getting lower and lower, and during the crisis, it continued to decrease. On the other hand, it can be seen that non-performing loans to total loan ratios were increasing worldwide. This situation was an outstanding aspect of China in such a financial crisis. Only three banks in China did not decide to hold mortgage-backed assets, and their share in total assets was limited. Due to this situation, we observe that there was not much problem in the Chinese financial sector, but in the Chinese stock market, these banks' market share had reduced significantly by $40 \%$. This was mainly because investors had lost their confidence in what would happen in the future (Sun, 2009). Banks decided to hold the same amount of their capital to total assets in China. The bank capital to asset ratio was almost stable at $6 \%$. Between 2007 and 2008, there was a reduction of 0.3 points. This reduction was relatively smaller than that of Turkey and Russia. There was also little increase in tax revenues during the global financial crisis. It was a good sign for China because there was a downward trend worldwide in this case. We think that the Chinese Government's policies were relatively successful in tax collecting issues despite not as much as Turkey.

As seen in Table 3, Chinese GDP growth was quite high in 2005, 2006, and 2007, and it reached the lowest level in 2009. After 2009, the GDP growth was around 9\%. In 2009, net FDI inflows were at the lowest levels in China. After this year, net FDI inflows had the highest levels. Unemployment rates were stable and around $4 \%$ during the mentioned period. In China, the inflation rate was quite low until 2007, and it increased to a $5 \%$ level before the crisis. After the crisis, the inflation rate was around $3 \%$. Table 3 also suggests that China had a current account surplus before the crisis. After the crisis, the amount of current account surplus decreased.

Table 3: Economic Indicators for China

\begin{tabular}{llllll}
\hline Year & $\begin{array}{l}\text { GDP } \\
\text { Growth }\end{array}$ & Net FDI Inflow & $\begin{array}{l}\text { Unemployment } \\
\text { Rate }\end{array}$ & Inflation Rate & $\begin{array}{l}\text { Current } \\
\text { Account to GDP }\end{array}$ \\
\hline 2005 & $\% 11.93$ & 104.10 Bn USD & $\% 4.2$ & $\% 1.77$ & $\% 5.79$ \\
\hline 2006 & $\% 12.71$ & 124.08 Bn USD & $\% 4.1$ & $\% 1.64$ & $\% 8.42$ \\
\hline 2007 & $\% 14.23$ & 156.24 Bn USD & $\% 4.0$ & $\% 4.81$ & $\% 9.94$ \\
\hline 2008 & $\% 9.65$ & 171.53 Bn USD & $\% 4.2$ & $\% 5.92$ & $\% 9.15$ \\
\hline 2009 & $\% 9.4$ & 131.05 Bn USD & $\% 4.3$ & $\%-0.72$ & $\% 4.76$ \\
\hline
\end{tabular}




\begin{tabular}{llllll}
\hline 2010 & $\% 10.63$ & 243.70 Bn USD & $\% 4.1$ & $\% 3.17$ & $\% 3.9$ \\
\hline 2011 & $\% 9.55$ & 280.07 Bn USD & $\% 4.1$ & $\% 3.55$ & $\% 1.82$ \\
\hline 2012 & $\% 7.86$ & 241.21 Bn USD & $\% 4.1$ & $\% 2.62$ & $\% 2.5$ \\
\hline
\end{tabular}

Source: World Bank Data

\section{IMPACTS ON SOUTH AFRICA ECONOMY}

Unlike the rest of the world, South Africa has not experienced net foreign direct investment inflows. We see only a three percent rise between 2006 and 2008. During the global economic crisis, FDI levels decreased. South Africa experienced the same patterns as China between 2001 and 2009 for portfolio investments. The only difference is that portfolio investment levels were not as high as in China. South Africa had a peak in 2006 with 14.5 billion dollars. After 2006, it began to decrease, and portfolio investment inflows turned negative, and there were 4.7 billion dollars of net capital outflow in 2008. Pre-crisis era (indicating between 2003 and 2007) South African economy had a growth of 3-5\% points every year. Behind this growth, commodities, especially coal, iron, and demand, played a crucial role. The decline in commodity prices also affected the South African economy's growth levels via decreasing merchandise trade. In this era, South Africa experienced a sharp decrease (almost 20\%) in merchandise trade (Baxter, 2009).

For South Africa, the current account balance was weaved after the 1960s. There was continually increasing current account deficit in the pre-crisis period; however, this trend reversed during the crisis, and the ratio of current account deficit to gross domestic product stood at $-1,53 \%$ in 2009 . Exports of South Africa were affected mainly by decreasing commodity prices and lower demand in the developed countries. Some fiscal policy decisions nearly balanced the situation, but many of the firms turned to survival mode, and it was essential to keep up with unemployment levels. Although the unemployment rate was at high levels, around $28 \%$ before the crisis, the unemployment rate changed during the global financial crisis. We think the restructuring of mineral firms helped to reduce these costs. Increase in unemployment was also relatively limited because of the FIFA 2010 World Cup held in South Africa. This event created job opportunities and counteracted the adverse effects of the crisis in terms of employment.

Only Investec took direct shock from the mortgage crisis. Investec reported 36 million pounds' subprime hit and a sharp fall in their share price, but this was a relatively small loss compared to the UK and the US Banks. Also, the leverage rate was highly low when we compared it to the US and the EU banks. While we observe a 50-60\% leverage rate globally, it was only $16 \%$ in South Africa. These details reflect the limited effect of the global financial crisis on South Africa's banking sector (Padayachee, 2010). Regulations of the banking sector were strict in South Africa, like in Turkey. South African banks were not allowed to use hybrid structures like in the US and EU, and they did not rely on the secondary structures on funding. Banks were also required to increase their capital adequacy ratios in standard times (Padayachee, 2010).

Thanks to these regulations, non-performing loans to the total loan ratio increased only slightly above compared to the rest of the world and the Russian Federation. Non-performing loans to total loans ratio showed a 2\% rise between 2008 and 2009 . That means loans defaulted or close to default showed a little increase in South Africa during the crisis. In the same period, tax revenues also showed a downward trend. Between 2007 and 2009, it decreased by nearly 3\% in South Africa. If we look at the world averages, in this case, it can be said that tax revenues showed a $2 \%$ decrease in average. Government expenditures increased by $3 \%$ between 2007 and 2009. It can be said that the stimulus package of government and preparations for the 2010 World Cup were influential in the increase of government expenditures.

The GDP growth rate of South Africa was around 5\% before the crisis, but after the crisis, it decreased to a $3 \%$ level. According to Table 4, net FDI inflows were rising until 2008, but after 2009, net FDI inflows to South Africa decreased due to the financial crisis. The unemployment rate was around $26 \%$ before the crisis, yet the unemployment rate decreased $24 \%$ after the crisis. As seen in Table 4, the inflation rate was around 2 or $3 \%$ before the financial crisis. During the crisis, it reached $10 \%$. After the financial crisis, the average inflation rate was $5 \%$. Like in Turkey, the current account deficit was low during the crisis.

Table 4: Economic Indicators for South Africa

\begin{tabular}{llllll}
\hline Year & GDP & Net FDI Inflow & $\begin{array}{l}\text { Unemployment } \\
\text { Rate }\end{array}$ & Inflation Rate & $\begin{array}{l}\text { Current } \\
\text { Account to GDP }\end{array}$ \\
\hline 2005 & $\% 5.27$ & $6.52 \mathrm{Bn}$ USD & $\% 29.25$ & $\% 2.06$ & $\%-3.10$ \\
\hline 2006 & $\% 5.60$ & $6.23 \mathrm{Bn}$ USD & $\% 28.48$ & $\% 3.24$ & $\%-4.44$ \\
\hline 2007 & $\% 5.36$ & $6.88 \mathrm{Bn}$ USD & $\% 26.66$ & $\% 6.17$ & $\%$ \\
\hline
\end{tabular}




\begin{tabular}{llllll}
\hline 2008 & $\% 3.19$ & 9.88 Bn USD & $\% 22.43$ & $\% 10.05$ & $\%-5.72$ \\
\hline 2009 & $\%-1.53$ & 7.69 Bn USD & $\% 23.53$ & $\% 7.26$ & $\%-2.62$ \\
\hline 2010 & $\% 3.04$ & 3.69 Bn USD & $\% 24.69$ & $\% 4.06$ & $\%-1.46$ \\
\hline 2011 & $\% 3.28$ & 4.13 Bn USD & $\% 24.65$ & $\% 5.01$ & $\%-2.23$ \\
\hline 2012 & $\% 2.21$ & 4.62 Bn USD & $\% 24.32$ & $\% 5.72$ & $\%-5.12$ \\
\hline
\end{tabular}

Source: World Bank Data

\section{IMPACTS ON INDIAN ECONOMY}

The GDP of India grew in the four years before the crisis. India had the second-highest growth rate after China among the countries we examined. Also, contracting in credit markets in advanced economies made it more difficult for Indian firms to take credits. When the firms could not reach the credit from external markets, they had to turn to domestic markets. Moreover, this caused the deprecation of the Rupee.

Indian Central Bank had to intervene in the foreign exchange markets. India's foreign exchange reserves reduced from 309 billion US dollars to 252 Billion US dollars to prevent Rupee's further deprecation and allow appreciation. Even though foreign direct investments did not decrease much in India, net portfolio investments inflow turned into an outflow, which means approximately 48 billion US dollars in 2008. This situation had a reflection on equity prices in India, and the BSE Index had $37.94 \%$. India experienced a quick recovery in the case of portfolio investments. In 2010 portfolio investments turned to the pre-crisis level.

Tight regulations in the banking sector prevented complex derivatives in bank balance sheets and off-balance sheet activities. The effect of swap and subprime credit markets was relatively limited on the Indian economy. Foreign Banks' share in Indian Banks did not exceed 5\% (Viswanathan, 2010). Before the crisis, there were not many non-performing loans relative to GDP in India, thanks to the measures we stated in the previous part. After 1999, non-performing loans were decreasing relative to GDP, and during the financial crisis, it stood at a 2-3\% level in India.

In the second half of 2008, Indian exports decreased by $15 \%$, mainly due to lower demand from European Countries and the United States. Notably, the United States was effective in India's export because of the share of the United States in software and IT technology export of India. Imports were also on the rise because of the high prices of oil and fertilizers, and thus current account deficit grew more significant in 2008 by -2.58 CA/GDP ratio.

Investors in the EU and the US became timider in 2008 during the crisis. Moreover, most of the investors had withdrawals from financial markets. Also, uncertainties about the future led to the consumption cut in India. In India, with the beginning of the global recession, inflation rates rose to $10.877 \%$ in 2009 , with fiscal expansion from $6 \%$ in 2006 . An increase in food prices played a significant role in this case since food prices increased by more than $10 \%$.

Food prices increased by more than $10 \%$ until March 2009. This rise in food prices, in turn, affected the budget of the household. Rising food prices caused problems in the agricultural sector and rural areas. This situation affected mainly farmers, migrant workers, and home-based women workers in India (Kumar et al., 2009). Unemployment rates did not change much during the global financial crisis, and there was a 0.4\% difference between 2007 and 2008.

According to Table 5, GDP growth was around 8\% before the crisis in India. After 2010, GDP growth lost its momentum, and the Indian economy started to grow more slowly. During the crisis, net FDI inflows peaked. The unemployment rate was mostly stable, around 5\% during the mentioned years. Inflation rates were low before 2007 in India, but after 2009, increasing to higher levels. Before the global financial crisis, India had lower current account deficits. As seen in Table 5, the current account deficit had increased.

Table 5: Economic Indicators for India

\begin{tabular}{llllll}
\hline Year & $\begin{array}{l}\text { GDP } \\
\text { Growth }\end{array}$ & Net FDI Inflow & $\begin{array}{l}\text { Unemployment } \\
\text { Rate }\end{array}$ & Inflation Rate & $\begin{array}{l}\text { Current } \\
\text { Account to GDP }\end{array}$ \\
\hline 2005 & $\% 7.92$ & 7.26 Bn USD & $\% 5.59$ & $\% 4.24$ & $\%-1.25$ \\
\hline 2006 & $\% 8.06$ & 20.02 Bn USD & $\% 5.45$ & $\% 5.79$ & $\%-0.98$ \\
\hline 2007 & $\% 7.66$ & 25.22 Bn USD & $\% 5.32$ & $\% 6.37$ & $\%-0.66$ \\
\hline 2008 & $\% 3.08$ & 43.40 Bn USD & $\% 5.28$ & $\% 8.34$ & $\%-1.95$ \\
\hline 2009 & $\% 7.86$ & 35.58 Bn USD & $\% 5.56$ & $\% 10.88$ & $\%-3.25$ \\
\hline 2010 & $\% 8.49$ & 27.39 Bn USD & $\% 5.63$ & $\% 11.98$ & \\
\hline
\end{tabular}




\begin{tabular}{llllll}
\hline 2011 & $\% 5.24$ & 36.49 Bn USD & $\% 5.63$ & $\% 8.85$ & $\%-3.42$ \\
\hline 2012 & $\% 5.49$ & 23.99 Bn USD & $\% 5.65$ & $\% 9.31$ & $\%-5.00$ \\
\hline
\end{tabular}

Source: World Bank Data

\section{IMPACTS ON BRAZILIAN ECONOMY}

Like most developing countries, Brazil also benefited from rising commodity prices, which led to a significant amount of current account surplus and economic growth. According to a study conducted by (Ferrari Filho, 2011), Brazilian growth rates were about $6 \%$ annually (Ferrari Filho, 2011). We see a decrease in exports from Brazil. Roughly half of the exports belonged to raw material exports for Brazil, and the other half consisted of manufacturing goods roughly. Because of the decline in demand from and decreasing commodity prices, Brazilian exports diminished (Williamson, 2009).

Parallel to the increase in domestic consumer demand, exports also increased in 2009. This rise in exports was mainly because of the steady recovery of the Chinese economy, and China became the primary trade partner of Brazil. Sao Paulo Stock Exchange Index had one of the most significant increases in value. The current account turned to negative values after 2008 with the effect of decreasing commodity prices. Also, growth rates turned negative with the effect of commodity negative in 2009, but recovery was quick thanks to the Brazilian Government's monetary and fiscal measures.

Fiscal measures were taken in two ways. The first of them was increasing the public sector payroll, and the second one is increasing social security payment and direct transfers to the private sector. The Brazilian economy began to improve in the second quarter of 2009 because of the fiscal, monetary, and soundness of intuitions. Before the crisis, unemployment rates were about $8 \%$ in Brazil, and the crisis's adverse effects seemed to be not valid for Brazil's unemployment rates. Unemployment rates stood at the same levels as previous rates, like China and India.

Similar to other countries, we cannot see a continuous increase in FDI in Brazil. In 2009, foreign direct investment decreased by $40 \%$, but it recovered quickly thereafter, and foreign direct investment increased by $166 \%$. The decrease in portfolio investment challenged the Brazilian economy during the crisis rather than FDI outflows. We see an increasing pattern for Brazil's portfolio investment between 2003 and 2007, but portfolio investment sharply decreased in 2008. Based on this figure, we can clearly say that we see a portfolio outflow of 34 billion US dollars.

The decrease in portfolio investment hit the real economy too. Because of scarcity in liquidation, many existing firms decreased their production level and canceled or postponed their investment options. However, in the service sector, the story was different. Because of the steady expansion of government expenditure, the crisis's effects in this sector were limited (Mendonça, 2010). In 1995, a banking crisis occurred in Brazil, similar to the one that occurred in Turkey. Many banks had troubles with solvency issues, and the Brazilian government had to take preventive measures to strengthen the banking system. Thanks to this protective measure, the Basel ratio for minimum capital requirement ratio was higher than in other countries in Brazil, with $11 \%$. In Brazilian banks, these rates were applied as $16 \%$ in general. Besides, the Brazilian banks did not buy toxic foreign certificates, and thus Brazilian banks were not affected much (Hoffman, 2011).

According to Table 6, Brazilian GDP grew until 2007, but after the crisis, it had quick restoration, and the GDP growth rate was about 7.52 in 2010. Net FDI inflows to Brazil were low before the global financial crisis, but net FDI inflows were much better after the financial crisis. Unemployment rates were high before 2008. After the crisis, the unemployment rates were lower compared to the pre-crisis levels. Inflation rates decreased until 2007, but after this year, it was around 5\%. Brazil had a current account surplus until the crisis, but they had a current account deficit after the crisis.

Table 6: Economic Indicators for Brazil

\begin{tabular}{llllll}
\hline Year & $\begin{array}{l}\text { GDP } \\
\text { Growth }\end{array}$ & Net FDI Inflow & $\begin{array}{l}\text { Unemployment } \\
\text { Rate }\end{array}$ & Inflation Rate & $\begin{array}{l}\text { Current } \\
\text { Account to GDP }\end{array}$ \\
\hline 2005 & $\% 3.20$ & 15.46 Bn USD & $\% 9.56$ & $\% 6.85$ & $\% 1.56$ \\
\hline 2006 & $\% 3.96$ & 19.37 Bn USD & $\% 8.63$ & $\% 4.18$ & $\% 1.23$ \\
\hline 2007 & $\% 6.07$ & 44.57 Bn USD & $\% 8.32$ & $\% 3.64$ & $\% 0.11$ \\
\hline 2008 & $\% 5.09$ & 50.71 Bn USD & $\% 7.34$ & $\% 5.67$ & $\%-1.66$ \\
\hline 2009 & $\%-0.12$ & 31.48 Bn USD & $\% 8.52$ & $\% 4.88$ & $\%-1.45$ \\
\hline 2010 & $\% 7.52$ & 82.39 Bn USD & $\% 7.73$ & $\% 5.03$ & $\%-3.57$ \\
\hline 2011 & $\% 3.97$ & 102.42 Bn USD & $\% 6.91$ & $\% 6.63$ & $\%-2.91$ \\
\hline 2012 & $\% 1.92$ & 92.56 Bn USD & $\% 7.18$ & $\% 5.40$ & $\%-3.39$ \\
\hline
\end{tabular}

Source: World Bank Data 


\section{CONCLUSION}

Except for Turkey and the Russian Federation, other countries were not primarily affected by the global financial crisis. In China, India, Brazil, and South Africa, GDP growth and unemployment rates did not change greatly. The difference between unemployment rates was limited to the previous rate in China, India, Brazil, and South Africa. In Russia and Turkey, we see significant differences with previous rates. For the current account balance, there is a whole different scenario. Commodity and oil exporter countries like Russia were severely affected by decreasing oil prices in terms of the current account. Meanwhile, oil and commodity importer countries like Turkey were less damaged and had their lowest current account deficit in this era. Another point we must add regarding Turkey is that tax revenues increased during the crisis because of the reasons analyzed in the second chapter. This is important because tax revenues decreased all over the world during the crisis.

In all countries, the banking and the financial sector showing similar trends. Developing countries did not take a direct hit to the banking sector because of robust regulations in the banking sector, relatively low toxic assets, and fiscal \& monetary measures taken in developing countries. However, in all countries, the stock exchange market was severely affected, especially in Russia, in this case, because investors had lost confidence and cashed out their money from the developing stock markets. In South Africa and Russia, it can be said that non-performing loans in total assets increased at least $4 \%$ during the crisis.

The biggest decline in portfolio equity was in Russia and Brazil with 33 billion US dollars. In China and Turkey, portfolio equity net outflow was limited. For example, in Turkey, portfolio equity investment decreased by 4 billion US dollars. For foreign direct investment, the most significant damage was taken in the Russian Federation and China. For both of the countries, we saw a sharp decrease of 40 billion US dollars. In other countries, foreign direct investments did not decrease sharply, but they lost 10 billion US dollars' worth of foreign direct investment during the global financial crisis.

Consequently, country-specific factors played an essential role in some countries. Especially for South Africa, the FIFA World Cup held in 2010 was influential in offsetting the crisis's adverse effects. Also, for the Russian Federation, Georgia's occupation in 2008 led to the protest against Russian goods, and therefore demand for Russian goods decreased. Another factor was the Sichuan earthquake in 2008, and most of the government stimulus package went reconstructing for the earthquake area in China. As a result, it can be said that Turkey and the Russian Federation took a direct hit from the crisis with substantial reductions in economic growth and unemployment rates. The probably less affected country is China from the global financial crisis thanks to the massive stimulus package. Therefore, GDP growth did not decrease much in China. Other countries (South Africa, Brazil, and India) were affected by the crisis, but it was not as big as a shock in Turkey and Russia, yet it was not as slight as in China (Leuing, 2006).

\section{REFERENCES}

Babacan, A. (2009). Global Financial Crisis and the Turkish Economy. Website: www2.Ise.ac.uk/publicEvents/pdf/20090917. (Retrieved 10/07/2020).

Bai, L. (2012). Effects of Global Financial Crisis on Chinese Export: A Gravity Model Study.

Barannik, D. (2010). In Search of “The Russian Path": Impact of the 2008 Crisis on Russia's Economic Policy.

Baxter, R. (2009). The Global Economic Crisis and Its Impact on South Africa and The Country's Mining Industry. Challenges for Monetary PolicyMakers in Emerging Markets, 105-116.

Cömert, H., \& Çolak, M. S. (2016). The Impacts of the Global Crisis on the Turkish Economy, And Policy Responses. In The Global South after the Crisis. Edward Elgar Publishing.

Conrad, J., Lanzeni, M. L., Nestmann, T., Giesel, B., \& Walter, N. (2009). Russia in the financial crisis and beyond. Deutsche Bank Research.

Ferrari Filho, F. (2011). Brazil's Response to the International Financial Crisis: How Did Financial Regulation and Monetary Policy Influence the Brazil's Economic Recovery?

Gotham, K. F. (2009). Creating Liquidity Out of Spatial Fixity: The Secondary Circuit of Capital and The Subprime Mortgage Crisis. International Journal of Urban and Regional Research, 33(2), 355-371.

Hoffmann, D. (2011). The Impact of the Financial Crisis in Brazil and Germany: A Comparative Analysis of Distinct Developments. Universida De Federal Do Rio De Jeneiro. 
Kumar, R., Debroy, B., Ghosh, J., Mahajan, V., \& Prabhu, K. S. (2009). Global Financial Crisis: Impact on India's Poor: Some Initial Perspectives. UNDP: India, available online at http://data.undp.org.in/FinancialCrisis/FinalFCP.pdf

Leunig, T. (2006). Time Is Money: A Re-Assessment of the Passenger Social Savings from Victorian British Railways. The Journal of Economic History, 66(3), 635-673.

Mendonça de Barros, J. R. (2010). The impact of the international financial crisis on Brazil (ARI), Real Instituto Elcano.

Mishkin, F. S. (2007). The Economics of Money, Banking, and Financial Markets. Pearson Education.

rod, V. (2010). Global Economic Recession: Effects and Implications for South Africa at a Time of Political Challenges. Claves De La Economia Mundial.

Rodrik, D. (2009). The Turkish Economy after the Crisis. Turkish Economic Association. Discussion Paper 2009/9. Retrieved October 4, 2014, from http://www.tek.org.tr/dosyalar/RODRIKTEK.paper.pdf.

Sun, X. (2009). The Impact of World Economic Crisis on China Economy.

Sutela, P. (2010). Russia's Response to the Global Financial Crisis. Электронный ресурс]. -Pежим доступа: http://carnegieendowment. org.

Viswanathan, K. G. (2010). The Global Financial Crisis and Its Impact on India. J. Int' I Bus. \& L., 9, 41.

Williamson, J. (2009). The Impact of the Global Financial Crisis on Brazil. Economics, Management, and Financial Markets, 4(1), $172-177$.

Yongding, Y. (2010). The Impact of the Global Financial Crisis on the Chinese Economy and China's Policy Responses. TWN Global Economy Series, (25).

https://www.worldbank.org/ (Retrieved 12/07/2020) 